\title{
Stock Structure of the Critically Endangered Clupisoma garua (Hamilton, 1822): An Investigation Based on Discriminant Analysis Approach
}

Ashfaqun Nahar ${ }^{1 *}$, Md Reaz Chaklader ${ }^{2}$, Muhammad Abu Bakar Siddik ${ }^{2}$, Ilham Ilham ${ }^{3}$, Hung Duc Pham ${ }^{4}$ and Sukham Munilkumar

${ }^{1}$ Department of Marine Fisheries and Oceanography, Patuakhali Science and Technology University, Patuakhali, Bangladesh

${ }^{2}$ Department of Fisheries Biology and Genetics, Patuakhali Science and Technology University, Patuakhali, Bangladesh

${ }^{3}$ Department of Aquatic Resources and Management, Jakarta Fisheries University, Indonesia

${ }^{4}$ Institute of Aquaculture, Nha Trang University, Khanh Hoa, Vietnam

5ICAR-Central Institute of Fisheries Education, Kolkata Centre, Salt Lake City, Kolkata, India

\begin{abstract}
The stock structure of critically endangered Clupisoma garua were examined based on morphometric characters. A total of 133 specimens were collected from four rivers located in the southern coastal zone of Bangladesh. Data were subjected to principal component analysis, discriminant function analysis and univariate analysis of variance. In discriminant function analysis, plotting first and second discriminant functions explained $88.4 \%$ and $9.9 \%$ of the between-group variation for morphometric analyses indicating the existence of three morphologically differentiated groups of $C$. garua. The first principal component (PC1) explained $82.41 \%$ of the total variation, while PC2 explained $4.62 \%$. The step-wise discriminant function analysis (DFA) retained six variables that significantly discriminated the populations. Using these variables, $82.0 \%$ of the original groups were classified into their correct samples and $79.70 \%$ of the cross validated groups omitting one procedure were classified into their correct samples. The result obtained from the study noticed significant differences among the populations.
\end{abstract}

Keywords: Stock structure; Morphometric characters; Discriminant analysis; Clupisoma garua; Bangladesh

\section{Introduction}

The study of morphological characters has been of strong interest in ichthyology in order to define or characterize fish stocks [1-4]. Generally, a 'fish stock' is a local population having genetic differences from other stocks and adapted to a particular environment [5]. Though genetic dissimilarities among stocks are a condition according to this definition, phenotypic variations still play a vital role in stock identification among groups of fish [6]. Various tools have been used for the purpose of stock identification among which the study of morphometric traits is one of the most frequently employed and costeffective methods. Morphometric characters have been successfully conducted on a number of fish species in order to identify stock structure including Trachurus mediterraneus [7], Limanda ferruginea [8], Clarias gariepinus [9], Pomatomus saltatrix [10], Rastrelliger kanagurta [11], Megalaspis cordyla [12], etc.

Knowledge of stock structure, distribution of fishing effort and mortality amongst the various components are essential to implement effective fishery management and worthwhile stock rebuilding programs, since each stock must be managed separately to optimize their yield [13-16]. Lack of proper knowledge on the fish and fishery management can lead to dramatic changes in the biological attributes and productivity of a species $[17,18]$. For delineation of fish stocks, morphological characters, such as body shape and meristic counts, have long been used and continue to be used successfully [19-22].

Clupisoma garua in the Siluriformes order is an important component of riverine and brackish water fisheries in Bangladesh known as Garua Bachcha which is preferable by all classes of consumers due to its availability, deliciousness and nutritive quality [23]. This species once extensively available in the coastal rivers in Bangladesh and also reported to have been found available in neighboring countries such as India, Myanmar, Nepal and Pakistan [24,25]. But over the decades, ever increasing anthropogenic and natural hazards squeeze the species geographical distribution across the country and subsequently the species is categorized as critically endangered in Bangladesh [26-28]. Very few studies have been conducted on C. garua especially stock differentiation from the selected rivers. Hence this study presents the first reference to investigate the stock structure and identify the best set of characters from different geographic coastal rivers of Bangladesh.

\section{Materials and Methods}

\section{Sampling}

A total of 133 specimens of C. garua were randomly collected from four coastal rivers, southern Bangladesh from Jan to Aug 2014. In general, 40 fish were targeted at each site for each sampling event. The species were caught by using commercial fishing net and majority of samples were collected with the help of municipal harvesters or management authorities. All specimens were placed in a cooler on ice prior to bring and were preserved with $70 \%$ ethanol and deposited in the Fish Laboratory, Faculty of Fisheries, Patuakhali Science and Technology University, Bangladesh. Sampling site locations, the numbers of samples analyzed per river as well as the GPS coordinates are presented in Table 1 and Figure 1.

\section{Laboratory work}

There are 162 individuals were analysed using 25 morphometric characters (Table 2). All specimens were measured with digital slide

*Corresponding author: Ashfaqun Nahar, Department of Marine Fisheries and Oceanography, Patuakhali Science and Technology University, Patuakhali-8602, Bangladesh, Tel: +880 1987-006723; E-mail: nahar@pstu.ac.bd

Received November 11, 2016; Accepted March 08, 2017; Published March 10 2017

Citation: Nahar A, Chaklader MR, Siddik MAB, Ilham I, Pham HD, et al. (2017) Stock Structure of the Critically Endangered Clupisoma garua (Hamilton, 1822): An Investigation Based on Discriminant Analysis Approach. J Aquac Res Development 8: 470. doi: 10.4172/2155-9546.1000470

Copyright: () 2017 Nahar A, et al. This is an open-access article distributed under the terms of the Creative Commons Attribution License, which permits unrestricted use, distribution, and reproduction in any medium, provided the original author and source are credited. 
Citation: Nahar A, Chaklader MR, Siddik MAB, Ilham I, Pham HD, et al. (2017) Stock Structure of the Critically Endangered Clupisoma garua (Hamilton, 1822): An Investigation Based on Discriminant Analysis Approach. J Aquac Res Development 8: 470. doi: 10.4172/2155-9546.1000470

Page 2 of 7

\begin{tabular}{|c|c|c|c|c|}
\hline Population & $\begin{array}{l}\text { Collection site } \\
\text { (District) }\end{array}$ & Location & $\begin{array}{l}\text { No. of } \\
\text { fish }\end{array}$ & $\begin{array}{l}\text { Date of } \\
\text { collection }\end{array}$ \\
\hline Burishwar river & Amtali (Patuakhali) & $22^{\circ} 12^{\prime} \mathrm{N} 90^{\circ} 20^{\prime} \mathrm{E}$ & 30 & 20.01 .14 \\
\hline Baleswar river & Mathbaria (Pirojpur) & $22^{\circ} 12^{\prime} \mathrm{N} 89^{\circ} 89^{\prime} \mathrm{E}$ & 35 & 01.03 .14 \\
\hline $\begin{array}{l}\text { Andarmanick } \\
\text { river }\end{array}$ & $\begin{array}{c}\text { Kalapara } \\
\text { (Patuakhali) }\end{array}$ & $21^{\circ} 92^{\prime} \mathrm{N} 90^{\circ} 14^{\prime} \mathrm{E}$ & 34 & 10.05 .14 \\
\hline Tentulia river & Gajalia (Barisal) & $22^{\circ} 33^{\prime} \mathrm{N} 90^{\circ} 65^{\prime} \mathrm{E}$ & 34 & 20.08 .14 \\
\hline
\end{tabular}

Table 1: Sources, number of specimens and date of collection of C. garua population.

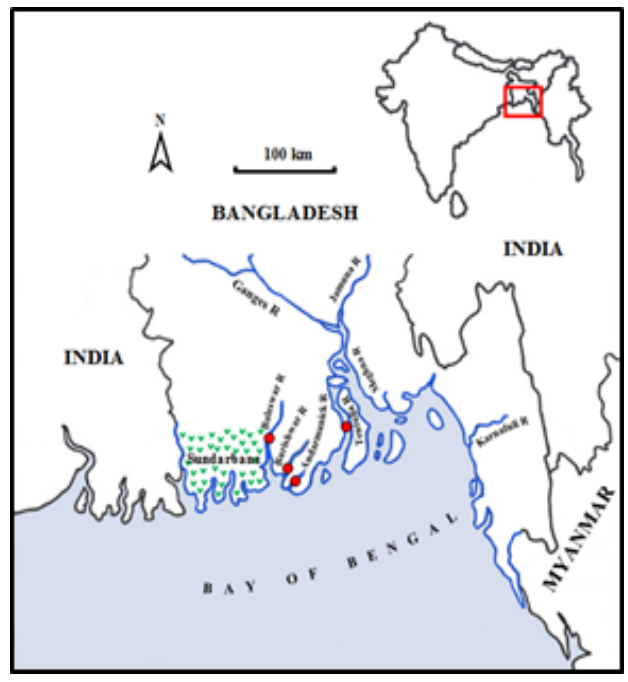

Figure 1: Sampling rivers of Clupisoma garua in the southern coastal zone of Bangladesh. calipers from the left side of the body up to the nearest $0.1 \mathrm{~cm}$ and total mass were weighed with a digital balance up to the nearest $0.1 \mathrm{~g}$.

\section{Data and statistical analysis}

A stepwise multivariate discriminant analysis was used for morphometric data to identify the combination of variables that best separate C. garua samples, since predictive ability of morphometric characters are statistically different $[29,30]$. Several univariate and multivariate analyses including regression analysis, allometric methods, multiple group principal component analysis, etc can be used to remove the size effect of the samples. The allometric methods are a significant help in achieving the size and shape separation and reasonably meet the statistical assumption [31]. Size-dependent variation was corrected by adjusting with an allometric method as suggested by Elliott et al. [32]:

$$
M_{a d j}=M\left(L_{s} / L_{0}\right)^{b}
$$

where $M$ is the original measurement, Madj the size adjusted measurement, $\mathrm{L}_{0}$ the standard length of the fish, $\mathrm{L}_{\mathrm{s}}$ the overall mean of standard length for all fish from all samples in each analysis, and b estimated for each character from the observed data as the slope of the regression of $\log \mathrm{M}$ on $\log \mathrm{L}_{0}$ using all fish from each group. The significance of the correlation between the transformed variables and standard length were tested by confirming with the allometric method obtained from the result [33]. Univariate analysis of variance (ANOVA) was executed for 25 morphometric characters in order to evaluate the significant difference among the four locations. In the present study, linear discriminant function analyses (DFA) and principal component analysis (PCA) were employed for the discrimination of four population populations. Principal component analysis which helps in morphometric data reduction [34], in decreasing redundancy

\begin{tabular}{|c|c|c|c|c|c|c|c|c|c|c|c|}
\hline \multirow[t]{2}{*}{ Characters } & \multicolumn{2}{|c|}{ Burishwar river } & \multicolumn{2}{|c|}{ Baleswar river } & \multicolumn{2}{|c|}{ Andarmanick river } & \multicolumn{2}{|c|}{ Tentulia river } & \multirow[t]{2}{*}{ Wilks lamba } & \multirow[t]{2}{*}{ F value } & \multirow[t]{2}{*}{$P$ value } \\
\hline & Mean & S.D. & Mean & S.D. & Mean & S.D. & Mean & S.D. & & & \\
\hline LT & 18.22 & 3.12 & 11.43 & 1.40 & 15.50 & 1.43 & 27.15 & 3.03 & 0.136 & 273.43 & $0.000^{*}$ \\
\hline LS & 14.38 & 2.54 & 8.97 & 1.09 & 12.21 & 1.06 & 23.01 & 3.26 & 0.142 & 259.37 & $0.000^{*}$ \\
\hline LF & 15.80 & 2.77 & 9.96 & 1.23 & 13.43 & 1.22 & 24.44 & 3.18 & 0.144 & 256.22 & $0.000^{*}$ \\
\hline $\mathrm{LH}$ & 2.76 & 0.47 & 1.92 & 0.24 & 2.44 & 0.25 & 4.56 & 0.88 & 0.211 & 161.22 & $0.000^{*}$ \\
\hline $\mathrm{H}_{\mathrm{D} \downarrow}$ & 1.98 & 0.36 & 1.50 & 0.25 & 1.74 & 0.23 & 3.98 & 0.91 & 0.209 & 163.11 & $0.000^{*}$ \\
\hline $\mathrm{D}_{2 \downarrow}$ & 3.44 & 0.76 & 2.02 & 0.268 & 2.74 & 0.41 & 5.58 & 1.32 & 0.254 & 126.13 & $0.000^{*}$ \\
\hline $\mathrm{L}_{\mathrm{BD} \downarrow}$ & 1.44 & 0.30 & 1.08 & 0.27 & 1.28 & 0.16 & 2.68 & 0.74 & 0.310 & 95.60 & $0.000^{*}$ \\
\hline $\mathrm{LE}_{1}$ & 0.82 & 0.16 & 0.57 & 0.10 & 0.78 & 0.10 & 1.69 & 0.40 & 0.207 & 164.93 & $0.000^{*}$ \\
\hline $\mathrm{E}_{2} \mathrm{H}$ & 1.23 & 0.21 & 0.73 & 0.08 & 1.04 & 0.19 & 1.96 & 0.33 & 0.184 & 190.22 & $0.000^{*}$ \\
\hline$E_{1} E_{2}$ & 0.71 & 0.20 & 0.62 & 0.15 & 0.62 & 0.10 & 0.89 & 0.26 & 0.726 & 16.21 & $0.000^{*}$ \\
\hline SnL & 1.17 & 0.23 & .88 & 0.14 & 1.09 & 0.12 & 1.75 & 0.63 & 0.521 & 39.61 & $0.000^{*}$ \\
\hline $\mathrm{LD}_{1}$ & 4.09 & 0.83 & 2.56 & 0.45 & 3.27 & 0.33 & 6.71 & 1.37 & 0.215 & 156.55 & $0.000^{*}$ \\
\hline $\mathrm{D}_{2} \mathrm{~S}$ & 8.97 & 1.64 & 5.09 & 0.58 & 7.36 & 1.41 & 14.14 & 2.00 & 0.159 & 227.14 & $0.000^{*}$ \\
\hline$D_{\downarrow}$ & 2.17 & 0.44 & 1.17 & 0.21 & 1.93 & 1.18 & 3.46 & 0.54 & 0.403 & 63.66 & $0.000^{*}$ \\
\hline$P_{\downarrow}$ & 2.42 & 0.41 & 1.41 & 0.24 & 2.08 & 0.22 & 3.93 & 0.68 & 0.169 & 212.01 & $0.000^{*}$ \\
\hline$v_{\downarrow}$ & 1.37 & 0.25 & 0.96 & 0.15 & 1.31 & 0.26 & 2.24 & 0.35 & 0.226 & 147.41 & $0.000^{*}$ \\
\hline $\mathrm{A}_{\downarrow}$ & 1.38 & 0.23 & 1.04 & 0.15 & 1.20 & 0.08 & 2.09 & 0.25 & 0.170 & 210.25 & $0.000^{*}$ \\
\hline $\mathrm{D}_{1} \mathrm{D}_{2}$ & 1.32 & 0.35 & 1.32 & 0.36 & 1.59 & 1.09 & 2.17 & 0.75 & 0.803 & 10.57 & $0.000^{*}$ \\
\hline$P_{1} P_{2}$ & 0.59 & 0.15 & 0.43 & 0.10 & 0.51 & 0.13 & 1.27 & 0.33 & 0.256 & 125.20 & $0.000^{*}$ \\
\hline$V_{1} V_{2}$ & 0.42 & 0.14 & 0.29 & 0.08 & 0.35 & 0.10 & 1.05 & 0.39 & 0.325 & 89.44 & $0.000^{*}$ \\
\hline $\mathrm{A}_{1} \mathrm{~A}_{2}$ & 4.25 & 0.78 & 2.40 & 0.35 & 3.48 & 0.49 & 6.49 & 1.11 & 0.187 & 187.35 & $0.000^{*}$ \\
\hline UJL & 1.05 & 0.21 & 0.73 & 0.15 & 0.94 & 0.17 & 1.91 & 0.53 & 0.306 & 97.67 & $0.000^{*}$ \\
\hline LJL & 0.82 & 0.14 & 0.70 & 0.83 & 0.73 & 0.14 & 1.53 & 0.49 & 0.677 & 20.52 & $0.000^{*}$ \\
\hline $\mathrm{ML}$ & 6.33 & 0.97 & 3.87 & 0.60 & 5.77 & 0.68 & 10.39 & 3.05 & 0.319 & 91.98 & $0.000^{*}$ \\
\hline$M_{n} L$ & 0.53 & 0.13 & 0.36 & 0.09 & 0.54 & 0.10 & 1.92 & 1.11 & 0.436 & 55.62 & $0.000^{*}$ \\
\hline
\end{tabular}

Table 2: Mean and standard deviation (S.D.) values and results of an ANOVA for 25 morphometric characters of $C$. garua from the Coastal rivers, southern Bangladesh (character descriptions given in Figure 1). 


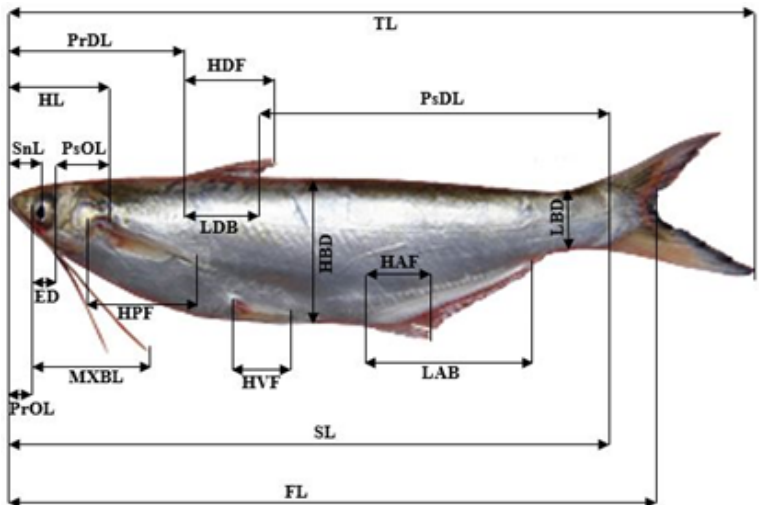

Figure 2: Schematic image of $C$. garua showing 25 morphometric attributes to infer morphological differences among $C$. garua populations. Total length (TL); Fork length (FL); Standard Length (SL); Head Length (HL); Head Depth (HD); Highest Body Depth (HBD); Lowest Body Depth (LBD); Pre-orbital Length (PrOL); Post-orbital Length (PsOL); Snout Length (SnL); Pre-dorsal Length (PrDL); Post-dorsal Length (PsDL); Height of Dorsal Fin (HDF); Height of Pectoral Fin (HPF); Height of Ventral Fin (HVF); Height of Anal Fin (HAF); Length of Dorsal Base (LDB); Length of Pectoral Base (LPB); Length of Ventral Base (LVB); Length of Anal Base (LAB); Upper Jaw Length (UJL); Lower Jaw Length (LJL); Maximum Barbell Length (MXBL); Minimum Barbell Length (MNBL).

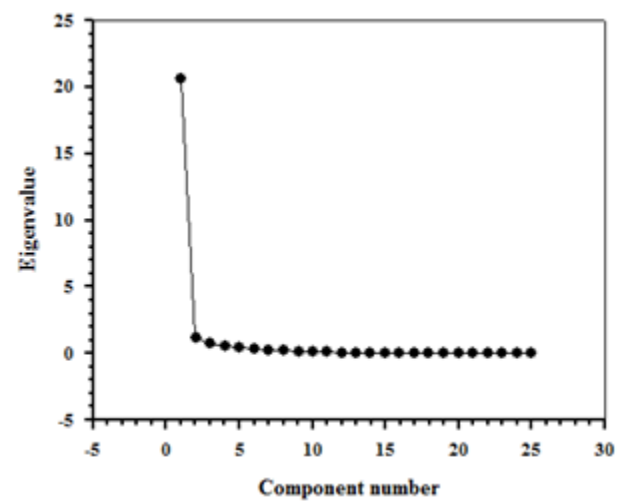

Figure 3: Screen plot of principal component in morphometric measurements for C. garua in four coastal rivers.

\begin{tabular}{|c|c|c|c|}
\hline Factor & Eigen-values & \% of variance & Cumulative\% \\
\hline PC1 & 20.75 & 82.99 & 82.99 \\
\hline PC2 & 1.09 & 4.35 & 87.34 \\
\hline
\end{tabular}

Table 3: Eigen values, percentage of variance and percentage of cumulative variance for 2 PC in C. garua morphometric measurements.

among the variables [35] and extracting a number of independent variables for population differentiation [36]. The Wilks' lamda was used to compare the differences between and among all groups. The DFA was used to estimate the percentage of correctly classified (PCC) fish. PCC was performed for a cross-validation to estimate the expected actual error rates of the classification functions. As a complement to discriminant analysis, morphometric distances among the individuals of the two groups were inferred to cluster analysis [34] by adopting the Euclidean distance as a measure of dissimilarity and the UPGMA (unweighted pair group method with arithmetical average) as the clustering algorithm. All data were analyzed using SPSS version 16.0, Statistica version 8.0 and Excel (Microsoft Office 2013).

\section{Results}

After allometric transformation, there was no significant correlation found with the standard length confirming that the size effect was removed from the data. A total of 133 specimens of $C$. garua were examined for 25 morphometric variables where none of showed insignificant variation $(\mathrm{P}>0.05)$ in univariate analysis of variance among four samples of C. garua (Table 2). The morphometric characters did not differ significantly $(\mathrm{P}>0.05)$ between both sexes, hence the data for both sexes were pooled for all subsequent analyses.

The contributions of the variables to principle components (PC) were examined with a view to determining which morphometric measurement most effectively differentiates populations. During this study Bartlett's Test of sphericity and the Kaiser-Meyer-Olkin (KMO) measure was accomplished to examine the suitability of the data for PCA. The Bartlett's Test of sphericity tests the hypothesis that the values of the correlation matrix equal to zero (small significance levels support the hypothesis that there are real correlations between the variables), and the KMO measure of sampling adequacy tests whether the partial correlation among variables is sufficiently high [37]. The statistics of KMO generally lies between 0 and 1 . Kaiser [38] recommends that the acceptable values of KMO are greater than 0.5 and Field [39] pointed out that between 0.5 and 0.7 are mediocre, between 0.7 and 0.8 are good, and between 0.8 and 0.9 are best suited. In the present study, the value of KMO for the overall matrix is 0.88 and the Bartlett's Test of sphericity is significant $(\mathrm{P}<0.01)$. The obtained results from $\mathrm{KMO}$ and Bartlett's test suggest that the sampled data are appropriate to proceed further factor analysis procedure.

For 25 morphometric measurements, Principal component analysis extracted two factors with eigen-values $>1$, explaining $87.34 \%$ of the variance (Figures 2 and 3). During this analysis, an eigenvalues exceeding 1 were included and others discarded for every characteristics. In the principal component analysis, the first principal component (PC I) accounted for $82.41 \%$ and was positively correlated with all linear dimensions of size, which indicate that there is size effect on the morphometric characters of analyzed populations (Table 3). The second principal component (PC II) accounted for $4.61 \%$ of total variance and was positively correlated to some variables and negatively correlated with others. The most significant loadings on PC1 were LT, LS, LF, LH, $\mathrm{H}_{\mathrm{D} \downarrow}, \mathrm{D}_{2 \downarrow}, \mathrm{L}_{\mathrm{BD} \downarrow}, \mathrm{LE}_{1}, \mathrm{E}_{2} \mathrm{H}, \mathrm{E}_{1} \mathrm{E}_{2}, \mathrm{SnL}, \mathrm{LD}_{1}, \mathrm{D}_{2} \mathrm{~S}, \mathrm{D}_{\downarrow}, \mathrm{P}_{\downarrow}, \mathrm{V}_{\downarrow}, \mathrm{A}_{\downarrow}$, $\mathrm{P}_{1} \mathrm{P}_{2}, \mathrm{~V}_{1} \mathrm{~V}_{2}, \mathrm{~A}_{1} \mathrm{~A}_{2}$ UJL, ML, $\mathrm{M}_{\mathrm{n}} \mathrm{L}$ while $\mathrm{D}_{1} \mathrm{D}_{2}$ was loaded to PC2 (Table 4). 'Eigen-value greater than unity' method was applied to reduce the number of factors to something below which is the rule for scree test [40]. In this test, scree plot was drawn by using eigen-values against the factors arranged in descending order along the X-axis. Nimalathasan [37] recommended that factor loading greater than 0.30 is considered significant, 0.40 more important, and 0.50 or greater is very significant. According to Mousavi-Sabet and Anvarifar [41], for parsimony, in this study, the factors with loadings were considered significant which were greater than 0.70 .

Wilk's $\lambda$ tests of discriminant analysis showed highly significant differences $(\mathrm{P}<0.001)$ in morphometric characters of all populations (Table 5).

Three discriminant functions (DFs) were formed during the analyses of discriminant function. The first discriminant function (DF I) accounted, the second discriminant function (DF II) and third discriminant function (DF III) accounted for $88.4 \%, 9.9 \%$ and $1.7 \%$, respectively of the total variation (Table 6). The morphometric measurements, LT, LS, LF, LH, $\mathrm{H}_{\mathrm{D}}, \mathrm{D}_{2 \downarrow}, \mathrm{L}_{\mathrm{BD} \downarrow}, \mathrm{LE}_{1}, \mathrm{E}_{2} \mathrm{H}, \mathrm{SnL}, \mathrm{LD}_{1}, \mathrm{D}_{2} \mathrm{~S}$, $D_{1}, P_{1}, V_{1}, A_{1}, D_{1} D_{2}, P_{1} P_{2}, V_{1} V_{2}, A_{1} A_{2}$ UJL, ML, $M_{n} L$ were contributed to DF I while $\mathrm{E}_{1} \mathrm{E}_{2}$ contributed to DF II (Table 6 and Figure 4), showing that these characters were the most important in distinguishing the 
population. The DF I vs DF II plot was drawn explaining $98.3 \%$ of total variance among the samples (Figure 4). The examined population formed three separate groups and showed intermingling among Andarmanick and Burishwar River stocks (Figure 4). The first group formed from the samples of Andarmanick and Burishwar River while

\begin{tabular}{|c|c|c|}
\hline \multirow{2}{*}{ Characters } & \multicolumn{2}{|c|}{ Principle Components } \\
\hline & PC 1 & PC 2 \\
\hline LT & 0.978 & 0.039 \\
\hline LS & 0.987 & 0.038 \\
\hline LF & 0.984 & 0.033 \\
\hline LH & 0.992 & -0.029 \\
\hline $\mathrm{H}_{\mathrm{D} \downarrow}$ & 0.966 & 0.004 \\
\hline $\mathrm{D}_{2 \downarrow}$ & 0.965 & -0.069 \\
\hline $\mathrm{L}_{\mathrm{BD} \downarrow}^{2 \downarrow}$ & 0.942 & -0.059 \\
\hline $\mathrm{LE}_{1}$ & 0.970 & 0.012 \\
\hline $\mathrm{E}_{2} \mathrm{H}$ & 0.967 & 0.004 \\
\hline $\mathrm{E}_{1} \mathrm{E}_{2}$ & 0.715 & -0.211 \\
\hline $\mathrm{SnL}$ & 0.853 & -0.262 \\
\hline $\mathrm{LD}_{1}$ & 0.965 & -0.063 \\
\hline$D_{2} S$ & 0.963 & -0.097 \\
\hline$D_{1}$ & 0.841 & 0.375 \\
\hline$P_{\downarrow}$ & 0.967 & 0.020 \\
\hline$v_{\downarrow}$ & 0.938 & 0.054 \\
\hline$A$ & 0.959 & 0.062 \\
\hline $\mathrm{D}_{1} \mathrm{D}_{2}$ & 0.430 & 0.844 \\
\hline $\mathrm{P}_{1} \mathrm{P}_{2}$ & 0.919 & -0.051 \\
\hline$V_{1} V_{2}$ & 0.908 & -0.096 \\
\hline $\mathrm{A}_{1} \mathrm{~A}_{2}$ & 0.964 & -0.058 \\
\hline UJL & 0.956 & -0.056 \\
\hline LJL & 0.670 & -0.235 \\
\hline ML & 0.922 & 0.089 \\
\hline$M_{n} L$ & 0.836 & 0.074 \\
\hline Percent of variance explained & 82.99 & 4.35 \\
\hline
\end{tabular}

Table 4: Component loadings of two principal components for morphometric characters in C. garua collected from coastal rivers.

\begin{tabular}{|c|c|c|c|c|}
\hline Functions & Wilks' Lambda & Chi-square & df & Sig. \\
\hline 1 through 3 & 0.044 & 395.924 & 21 & 0.000 \\
\hline 2 through 3 & 0.429 & 106.982 & 12 & 0.000 \\
\hline 3 & 0.853 & 20.072 & 5 & 0.001 \\
\hline
\end{tabular}

Table 5: Wilks' lambda tests (functions 1 through 3) for morphometric C. garua for verifying dissimilarities among four stocks separately compared using discriminant function analysis.

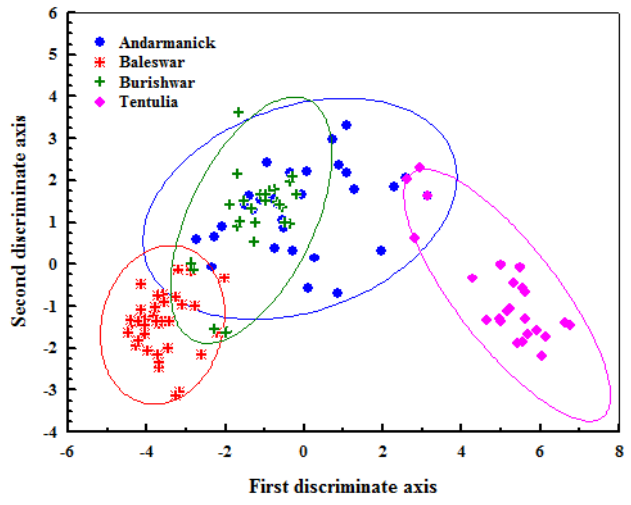

Figure 4: Scatter plot of the 1st 2 canonical discriminant scores from the discriminant function analysis (DFA) for morphometric characters of $C$. garua collected from the coastal rivers.

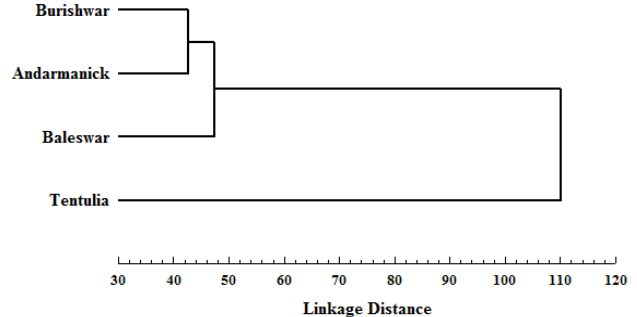

Figure 5: Dendogram of 25 morphometric based on UPGMA cluster analysis for C. garua in four coastal rivers, Bangladesh.

\begin{tabular}{|c|c|c|c|}
\hline \multirow[b]{2}{*}{ Characters } & \multicolumn{3}{|c|}{ Function } \\
\hline & DF I (88.4\%) & DF II $(9.9 \%)$ & DF III (1.7\%) \\
\hline $\mathrm{LT}$ & $0.848^{*}$ & 0.094 & -0.170 \\
\hline LS & $0.825^{*}$ & 0.025 & -0.127 \\
\hline LF & $0.824^{*}$ & 0.048 & -0.154 \\
\hline $\mathrm{LH}$ & $0.660^{*}$ & -0.124 & 0.100 \\
\hline $\mathrm{H}_{\mathrm{D} \downarrow}$ & $0.641^{*}$ & -0.393 & 0.268 \\
\hline $\mathrm{D}_{2 \downarrow}$ & $0.633^{*}$ & -0.041 & -0.018 \\
\hline $\mathrm{L}_{\mathrm{BD} \downarrow}$ & $0.494^{*}$ & -0.250 & 0.130 \\
\hline $\mathrm{LE}_{1}$ & $0.676^{*}$ & -0.183 & 0.246 \\
\hline $\mathrm{E}_{2} \mathrm{H}$ & $0.716^{*}$ & -0.013 & 0.178 \\
\hline $\mathrm{E}_{1} \mathrm{E}_{2}$ & 0.201 & -0.116 & $-0.226^{*}$ \\
\hline SnL & $0.403^{*}$ & -0.088 & -0.029 \\
\hline $\mathrm{LD}_{1}$ & $0.694^{*}$ & -0.156 & -0.129 \\
\hline $\mathrm{D}_{2} \mathrm{~S}$ & $0.719^{*}$ & 0.091 & -0.090 \\
\hline$D_{\downarrow}$ & $0.464^{*}$ & 0.134 & 0.147 \\
\hline$P_{\downarrow}$ & $0.748^{*}$ & 0.054 & 0.036 \\
\hline$V_{\downarrow}$ & $0.621^{*}$ & -0.034 & 0.401 \\
\hline$A_{\downarrow}$ & $0.741^{*}$ & -0.215 & -0.053 \\
\hline$D_{1} D_{2}$ & $0.169^{*}$ & 0.055 & 0.019 \\
\hline$P_{1} P_{2}$ & $0.546^{*}$ & -0.223 & 0.042 \\
\hline$V_{1} V_{2}$ & $0.497^{*}$ & -0.355 & 0.013 \\
\hline $\mathrm{A}_{1} \mathrm{~A}_{2}$ & $0.742^{*}$ & 0.078 & -0.179 \\
\hline UJL & $0.657^{*}$ & -0.065 & 0.125 \\
\hline LJL & $0.218^{*}$ & -0.083 & 0.091 \\
\hline ML & $0.492^{*}$ & 0.045 & 0.189 \\
\hline$M_{n} L$ & $0.494^{*}$ & -0.162 & 0.266 \\
\hline
\end{tabular}

Table 6: Morphometric measurement contributions to discriminant functions of $C$ garua collected from four coastal rivers of Bangladesh.

the second and third groups formed from the samples of the Baleswar and Tentulia rivers, respectively (Figure 4). The Baleswar and Tentulia River fish samples showed a clear separation from each other as well as from the samples of others, and recognized the existence of different stocks in these rivers.

The dendrogram (Figure 5) obtained from the cluster analysis based on morphometric characters also confirming the high degree of heterogeneity between the Baleswar and Tentulia river population and the relative homogeneity between the Andarmanick and Burishwar river population.

A correct classification of individuals into their original population varied between $66.7 \%$ and $97.1 \%$ and Cross-validated classification varied between $67.6 \%$ and $97.1 \%$ by canonical analysis. Discriminant function analysis showed higher values $(82.0 \%)$ for the overall allotment of individuals into their original populations and the crossvalidation test results were com- parable to the results obtained from PCC (Table 7). The percentage of correctly classified fishes was highest 


\begin{tabular}{|c|c|c|c|c|c|c|}
\hline & $\begin{array}{c}\text { Burishwar } \\
\text { river }\end{array}$ & $\begin{array}{c}\text { Baleswar } \\
\text { river } \\
\text { Original group }\end{array}$ & $\begin{array}{c}\text { Andarmanick } \\
\text { river }\end{array}$ & $\begin{array}{c}\text { Tentulia } \\
\text { river }\end{array}$ & Total \\
\hline Burishwar river & 20 & 1 & 9 & 0 & 30 \\
\hline$\%$ & 66.7 & 3.3 & 30.0 & 0.0 & 100.0 \\
\hline Baleswar river & 0 & 34 & 1 & 0 & 35 \\
\hline$\%$ & 0.0 & 97.1 & 2.9 & 0.0 & 100.0 \\
\hline $\begin{array}{c}\text { Andarmanick } \\
\text { river }\end{array}$ & 3 & 7 & 24 & 0 & 34 \\
\hline$\%$ & 8.8 & 20.6 & 70.6 & 0.0 & 100.0 \\
\hline Tentulia river & 3 & 0 & 0 & 31 & 34 \\
\hline$\%$ & 8.8 & 0.0 & 0.0 & 91.2 & 100.0 \\
\hline & & Cross-validated & & & \\
\hline Burishwar river & 19 & 1 & 9 & 1 & 30 \\
\hline$\%$ & 63.3 & 3.3 & 30.0 & 3.3 & 100.0 \\
\hline Baleswar river & 0 & 34 & 1 & 0 & 35 \\
\hline$\%$ & 0.0 & 97.1 & 2.9 & 0.0 & 100.0 \\
\hline Andarmanick & 4 & 7 & 23 & 0 & 34 \\
\hline river & 11.8 & 20.6 & 67.6 & 0.0 & 100.0 \\
\hline$\%$ & 4 & 0 & 0 & 30 & 34 \\
\hline Tentulia river & 41.8 & 0.0 & 0.0 & 88.2 & 100.0 \\
\hline$\%$ & 11.0 & & & \\
\hline$\%$ & & & & & & \\
\hline
\end{tabular}

Table 7: Results of a discriminant function analysis (DFA) showing the number and percentage of individuals classified into each group for morphometric characters from the original matrix.

in the Baleswar River (97.1\%) followed by Tentulia, Andarmanick and Burishwar River. Misclassification was evident from Andarmanick sampling stations (30.0\%).

\section{Discussion}

Fish exhibit higher degrees of variation within and between populations among all vertebrates and morphological variation are more susceptible to different environmental factors [42]. Such variation in morphology is commonly found due to different environmental condition and the isolation of portions of a population within local habitat conditions. Notable variation in phenotypic and genetic may occur among fish populations within a species due to a sufficient degree of isolation, as a result need for separation and management of distinct populations [43]. Such variation can occur through different processes. For example, reproductive isolation between different stocks of fishes may arise by homing to different spawning areas [44], or by hydrographic features that reduce or prevent migration between areas [45]. Failure to recognize or to account for stock complexity in management units has led to an erosion of spawning components, resulting in a loss of genetic diversity and other unknown ecological consequences [15].

The phenotypic variance was observed among the specimen of $C$. garua revealing the existence of three morphologically discriminated stocks viz., the Andarmanick and Burishwar River population, the Baleshwar River population and the Tentulia River population. The divergence among the samples may be related with phenotypic heterogeneity and geographic distance and showing limited intermingling among the populations of Tentulia River and the Baleshwar River. Fish samples from the Andarmanick and Burishwar River population were morphometrically similar to each other; the extent of overlapping between the populations of Kalapara and Amtali could have been sufficient to prevent morphometric variation between the two samples. The Tentulia samples were highly deviated from the other samples which might be due to the geographic isolation and environmental condition of the river. The four selected Rivers has connection with the Bay of Bengal. Despite having connection, $C$. garua showed morphometric variations to Baleshwar and Tentulia rivers. Geographical isolation and environmental parameters might be the possible cause for morphological distinction, which could have been impeding the movement of fishes to intermingle with populations of other selected rivers.

Different unbalanced hydrological conditions such as differences in alkalinity, current pattern, temperatures and turbidity of coastal rivers could be a consequence of phenotypic plasticity of fish which might be the possible cause for variation among the stocks of four populations. The nearness between stocks may be due to their homogenous habitat features and to environmental impacts. These variation may be related with genetics or different environmental factors might be influenced the phenotypic plasticity of fish in each area [46,47]. Similar observation was reported by Boussou et al. [48] environmentallyinduced morphological differences were found for Chromidotilapia guntheri among the tributaries of the Tanoe River which were geographically close to each other. Quilang et al. [49] discerned similar observations in silver perch Leiopotherapon plumbeus from three lakes in the Philippines and reported physico-chemical characteristics of the water were responsible for the discrimination.

Phenotypic plasticity and genetic concerns due to the distinct environmental attributes were attributed for these significant difference. Akbarzadeh et al. [50] found morphologically-distinct populations and summarized that these divergence among the sticks may be due to the body shape variation and not to size effects. Similarly in our present findings, morphological dissimilarities within the coastal rivers may be solely related to body shape variation, since allometric transformation were successfully applied to remove the size effect.

For the discrimination of different stocks of the same species, discriminant function analysis (DFA) could be a worthwhile method [51]. In the present study, $82.0 \%$ of individuals were correctly classified into their respective groups by DFA which showed intermingling among some of the populations. Silva et al. [22] conducted research on the sardine (Sardina pilchardus) from different areas of the northeastern Atlantic and the western Mediterranean and reported significant morphometric heterogeneity among different populations by applying DFA. PCA were performed partly to confirm the DFA segregation where PC1 and PC2 scores for each sample were used to draw a graphs, showing some overlapping and clear distinct among four coastal population. This analysis confirmed that the variation in morphological measurements was evident in all attributes except LDB among different populations of C. garua. Chaklader et al. [2] also reported similar observations in Polynemus paradiseus from three coastal rivers, where the environmental parameters were played a vital role in spatial distribution, movement and isolation of fish stocks. Sometimes it becomes problematic to expound the causes of morphological variances between populations [1]. Genetics and environment, and their interaction determine the morphological characteristics of fish suggested by Poulet et al., [52]. Environmental factors remain susceptible during the early development stages, when the individual's phenotype is more influenced by environmental factors $[53,54]$. Apparently the different location of river impoundments can lead to an enhancement of pre-existing genetic differences, providing a high interpopulation structuring [55]. Therefore, the observed morphological variations in the present study are probably due to genetic differences among the populations.

\section{Conclusion}

It may be summarized that $C$. garua has different stocks in 
Citation: Nahar A, Chaklader MR, Siddik MAB, Ilham I, Pham HD, et al. (2017) Stock Structure of the Critically Endangered Clupisoma garua (Hamilton, 1822): An Investigation Based on Discriminant Analysis Approach. J Aquac Res Development 8: 470. doi: 10.4172/2155-9546.1000470

Page 6 of 7

the selected rivers while the two River sampling stations did not demonstrate dissimilarity in the fish stock. These distinction observed in the present study are probably influenced by both genes and environment. Hence, further study is warranted to explore the genetic basis for stock discrimination to corroborate with the present findings. Application of molecular genetic markers such as microsatellite and mtDNA applications along with morphometric studies is highly recommended to further examine the genetic component of phenotypic discreteness between geographic regions which would be effective to facilitate the development of appropriate management strategies in relation to the fishery and conservation of C. garua populations in selected rivers. However based on this morphometric study, our result should be helpful to develop proper guidelines for the implementation of appropriate mesh sizes in all selected rivers of the coastal region, may help in sustaining this resource for future use.

\section{References}

1. Cadrin SX (2000) Advances in morphometric identification of fishery stocks. Rev Fish Biol Fish 10: 91-112.

2. Chaklader MR, Siddik MAB, Nahar A (2015) Taxonomic diversity of paradise threadfin Polynemus paradiseus (Linnaeus, 1758) inhabiting southern coastal rivers in Bangladesh. Sains Malaysiana 44: 1241-1248.

3. Siddik M, Chaklader M, Hanif M, Islam M, Sharker M, et al. (2016a) Stock identification of critically endangered olive barb, Puntius sarana (Hamilton, 1822 ) with emphasis on management implications. J Aquac Res Development 7: 411.

4. Siddik MAB, Hanif MA, Chaklader MR, Nahar A, Mahmud S (2016b) Fishery biology of gangetic whiting Sillaginopsis panijus (Hamilton, 1822) endemic to Ganges delta, Bangladesh. Egyptian Journal of Aquatic Research 41: 307-313.

5. MacLean JA, Evans DO (1981) The stock concept, discreteness of fish stocks, and fisheries management. Can J Fish Aquat Sci 38: 1889-1898.

6. Costa JL, De Almeida PR, Costa MJ (2003) A morphometric and meristic investigation of Lusitanian toadfish Halobatrachus diductilus (Bloch and Schneider, 1081): evidence of population fragmentation on Portuguese coast. Sci Mar 67: 219-231.

7. Turan C (2004) Stock identification of Mediterranean horse mackere (Trachurus mediterraneus) using morphometric and meristic characters. ICES J Mar Sci 61: 774-781.

8. Cadrin SX, Silva VM (2005) Morphometric variation of yellowtail flounder. ICES J Mar Sci 62: 683-694.

9. Turan C, Yalcin S, Turan F, Okur E, Akyurt I (2005) Morphometric comparisons of African catfish, Clarias gariepinus, populations in Turkey. Fol Zool 54: 165-172.

10.Turan C, Oral M, Ozturk B, Duzgunes E (2006) Morphometric and meristic variation between stocks of bluefish (Pomatomus saltatrix) in the Black, Marmara, Aegean and Northeastern Mediterranean seas. Fish Res 79: 139-147.

11. Jayasankar P, Thomas PC, Paulton MP, Mathew J (2004) Morphometric and genetic analyzes of Indian mackerel (Rastrelliger kanagurta) from peninsular India. Asian Fish Sci 17: 201-215.

12. Sajina AM, Chakraborty SK, Jaiswar AK, Pazhayamadam DG, Sudheesan D (2011) Stock structure analysis of Megalaspis cordyla (Linnaeus, 1758) along the Indian coast based on truss network analysis. Fish Res 108: 100-105.

13. Grimes CB, Johnson AG, Faber WA (1987) Delineation of king mackere (Scomberomorus cavalla) stocks along the US east coast and in the Gulf of Mexico. Technical Memorandum NMFS-SEFC-199.

14. Carvalho GR, Hauser $L$ (1994) Molecular genetics and the stock concept in fisheries. Reviews in Fish Biology and Fisheries 4: 326-350.

15. Begg GA, Friedland KD, Pearce JB (1999) Stock identification and its role in stock assessment and fisheries management: An overview. Fish Res 43: 1-8.

16. Siddik MAB, Nahar A, Ahamed F, Masood Z, Hossain MY (2013) Conservation of critically endangered olive barb Puntius sarana (Hamilton, 1822) through artificial propagation. Our nature 11: 96-104
17. Altukhov YP (1981) The stock concept from the viewpoint of population genetics. Canadian Journal of Fisheries and Aquatic Sciences 38: 1523-1538.

18. Smith PJ, Francis R, McVeagh M (1991) Loss of genetic diversity due to fishing pressure. Fisheries Research 10: 309-316.

19. Chaklader MR, Siddik MAB, Hanif MA, Nahar A, Mahmud S, et al. (2016) Morphometric and meristic variation of endangered pabda catfish, Ompok pabda (Hamilton-Buchanan, 1822) from southern coastal waters of Bangladesh. Pakistan Journal of Zoology 48: 233-240.

20. Villaluz AC, Maccrimmon HR (1988) Meristic variations in milkfish Chanos chanos from Philippine waters. Marine Biology 97: 145-150.

21. Haddon M, Willis TJ (1995) Morphometric and meristic comparison of orange roughy (Hoplostethus atlanticus, Trachichthyidae) from the Puysegur Bank and Lord Howe Rise, New-Zealand, and its implications for stock structure. Marine Biology 123: 19-27.

22. Silva A (2003) Morphometric variation among sardine (Sardina pilchardus) populations from the northeastern Atlantic and the western Mediterranean ICES Journal of Marin Science 60: 1352-1360.

23. Galib SM, Samad MA, Mohsin ABM, Flowra FA, Alam MT (2009) Present Status of Fishes in the Chalan Beel- the Largest Beel (Wetland) of Bangladesh. Int J Ani Fish Sci 2: 214-218.

24. Rahman AKA (1989) Freshwater Fishes of Bangladesh, (1stedn). Zoological Society of Bangladesh, Department of Zoology, University of Dhaka, Dhaka.

25. Talwar PK, Jhingran AG (1991) Inland Fishes of India and Adjacent Countries, Oxford \& IBH Publishing Co. Pvt. Ltd. New Delhi-Calcutta, India.

26. IUCN (2000) Red book of threatened fishes of Bangladesh, IUCN- The world conservation union.

27. Hanif MA, Siddik MAB, Chaklader MR (2015a) Fish diversity in the southern coastal waters of Bangladesh: present status, threats and conservation perspectives. Croatian Journal of Fisheries 73: 251-274.

28. Hanif MA, Siddik MAB, Chaklader MR, Mahmud S, Nahar A, et al. (2015b) Biodiversity and conservation of threatened freshwater fishes in Sandha River, South West Bangladesh. World Applied Sciences Journal 33: 1497-1510.

29. Ihssen PE, Booke HE, Casselman JM, McGlade JM, Payne NR, et al. (1981) Stock identification: materials and methods. Can J Fish Aquat Sci 38: 1838 1855.

30. Hair JF, Anderson R, Tatham R, Black W (1996) Multivariate data analysis with readings. Prentice Hall Inc., New Jersey, USA.

31. Reist JD (1985) An empirical evaluation of several univariate methods that adjust for size variation in morphometric variation. Canadian Journal of Zoology 63: $1429-1439$.

32. Elliott NG, Haskard K, Koslow JA (1995) Morphometric analysis of orange roughy (Hoplostethus atlanticus) off the continental slope of southern Australia. Journal of Fish Biology 46: 202-220.

33. Turan C (1999) A note on the examination of morphometric differentiation among fish populations: the truss system. Turk J Zool 23: 259-263.

34. Veasey EA, Schammass EA, Vencovsky R, Martins PS, Bandel G (2001) Germplasm characterization of Sesbania accessions based on multivariate analyses. Genet Resour Crop Evol 48: 79-90.

35. Samaee M, Patzner RA, Mansour N (2009) Morphological differentiation within the population of Siah mahi, Capoeta capoeta gracilis, (Cyprinidae, Teleostei) in a river of the south Caspian Sea basin: A pilot study. J Appl Ichthyol 25 583-590.

36. Samaee SM, Mojazi-Amiri B, Hosseini-Mazinani SM (2006) Comparison of Capoeta capoeta gracilis (Cyprinidae, Teleostei) populations in the south Caspian Sea River basin, using morphometric ratios and genetic markers. Folia Zool 55: 323-335.

37. Nimalathasan B (2009) Determinants of key performance indicators (KPIs) of private sector banks in Sri Lanka: an application of exploratory factor analysis. Ann Stefan cel Mare Univ Suceava Fac Econ Publ Admin 9: 9-17.

38. Kaiser HF (1974) An index of factorial simplicity. Psychometrika 39: 31-36.

39. Field A (2000) Discovering statistics using SPSS for Windows. Sage, London.

40. Cattell RB (1966) The screen test for the number of factors, multivariate. Behav Res 1: 245-276. 
Citation: Nahar A, Chaklader MR, Siddik MAB, Ilham I, Pham HD, et al. (2017) Stock Structure of the Critically Endangered Clupisoma garua (Hamilton, 1822): An Investigation Based on Discriminant Analysis Approach. J Aquac Res Development 8: 470. doi: 10.4172/2155-9546.1000470

41. Mousavi-Sabet H, Anvarifar H (2013) Landmark-based morphometric variation between Cobitis keyvani and Cobitis faridpaki (Pisces: Cobitidae), with new habitat for C. faridpaki in the southern Caspian Sea basin. Folia Zool 62: 167-175.

42. Wimberger PH (1992) Plasticity of fish body shape: the effects of diet, development, family and age in two species of Geophagus (Pisces: Cichlidae). Biol J Linn Soc 45: 197-218.

43. Turan C, Erguden D, Gurlek M, Basusta N, Turan (F 2004) Morphometric structuring of the anchovy (Engraulis encrasicolus L.) in the black. Aegean and Northeastern Mediterranean seas. Turk J Vet Anim Sci 28: 865-871.

44. Hourston AS (1982) Homing by Canada's west coast herring to management units and divisions as indicated by tag recoveries. Can J Fish Aquat Sci 39: 1414-1422.

45. lles TD, Sinclair M (1982) Atlantic herring stock discreteness and abundance. Science 215: 627-633.

46. Murta AG (2000) Morphological variation of horse mackerel (Trachurus trachurus) in the Iberian and North African Atlantic: implications for stock identification. ICES J Mar Sci 57: 1240-1248.

47. Mir JI, Sarkar UK, Dwivedi AK, Gusain OP, Jena JK (2013) Stock structure analysis of Labeo rohita (Hamilton, 1822) across the Ganga basin (India) using a truss network system. J Appl Ichthyol 29: 1097-1103.

48. Boussou CK, Konan FK, Edia OE, Ouattara M, Bony YK, et al. (2010) Morphometric analysis of populations of Chromidotilapia guntheri (Sauvage,
1882) (Cichlidae, perciformes) in four coastal rivers of $C^{\wedge}$ ote d'lvoire (West Africa). Panam J Aquat Sci 5: 387-400.

49. Quilang JP, Basiao ZU, Pagulayan RC, Roderos RR, Barrios EB (2007) Meristic and morphometric variation in the silver perch, Leiopotherapon plumbeus (Kner, 1864), from three lakes in the Philippines. J Appl Ichthyol 23: 561-567.

50. Akbarzadeh A, Farahmand H, Shabani AA, Karami M, Kaboli M, et al. (2009) Morphological variation of the pikeperch Sander lucioperca (L.) in the southern Caspian Sea, using a truss system. J Appl Ichthyol 25: 576-582.

51. Karakousis Y, Triantaphyllidis C, Economidis PS (1991) Morphological variability among seven populations of brown trout, Salmon trutta L., in Greece. J Fish Biol 38: 807-817.

52. Poulet N, Berrebi P, Crivelli AJ, Lek S, Argillier C (2004) Genetic and morphometric variations in the pikeperch (Sander lucioperca L.) of a fragmented delta. Arch Hydrobiol 159: 531-554.

53. Pinheiro A, Teixeira CM, Rego AL, Marques JF, Cabral HN (2005) Genetic and morphological variation of Solea lascaris (Risso, 1810) along the Portuguese coast. Fish Res 73: 67-78.

54. Sharker MR, Siddik MAB, Nahar A, Shahjahan M, Faroque AA (2015) Genetic differentiation of wild and hatchery populations of Indian major carp Cirrhinus cirrhosis in Bangladesh. Journal of Environmental Biology 36: 1223-1227.

55. Esguicero ALH, Arcifa SA (2010) Fragmentation of a Neotropical migratory fish population by a century-old dam. Hydrobiol 638 : 41-53. 